\title{
Biographies of Two African American Women in Religious Music: Clara Ward and Rosetta Tharpe
}

\author{
Nana A. Amoah-Ramey Ph.D. \\ Indiana University \\ Department of African American and African Diaspora Studies \\ College of Arts and Sciences \\ Ballantine Hall 678 \\ Bloomington IN, 47405, USA
}

\begin{abstract}
This paper's focus is to compare the lives, times and musical professions of two prominent African American womenClara Ward and Rosetta Thorpe - in religious music. The study addresses the musical careers of both women and shows challenges that they worked hard to overcome, and how their relationship with other musicians and the public helped to steer their careers by making them important figures in African American gospel and religious music. In pursuing this objective, I relied on manuscripts, narratives, newspaper clippings, and published source materials. Results of the study points to commonalities or similarities between them. In particular, their lives go a long way to confirm the important contributions they made to religious music of their day and even today.
\end{abstract}

Keywords: African American Gospel and Religious Music, Women, Gender, Liberation, Empowerment

\section{Overview}

This paper is structured as follows: It begins with a brief discussion of the historical background of gospel and sacred music. This is followed by an examination of the musical careers of Clara Ward and Rosetta Thorpe with particular attention to the challenges they faced and the strategies they employed to overcome such challenges; and by so doing becoming major figures performing this genre (gospel and sacred music) of music. The next section is an elucidation and exemplification of the extent to which Clara Ward and Rosetta Thorpe's music helped to liberate and empower them and also touched the lives of millions. The two quotations below (one by Horace Clarence Boyer, a Gospel Scholar, and the other by Willa Ward, Clara's only sister) set the scene for the core part of the paper.

"Sister Rosetta Tharpe did more than anyone else in introducing the music of the Negro Church to the World," says Gospel Scholar, Horace Clarence Boyer.

"Clara Ward is a woman who had pulled Gospel singing from local black churches and spread it lovingly over the Universe 'the miracle girl'." Says Willa Ward, Clara's only sister.

\section{Historical Background of Gospel and Religious Music}

The process of transporting slaves from their African abodes to the new world resulted in the seizure of their political, cultural and social institutions. Subsequently, the enslaved Africans were thrust into an alien, and often, harsh environment that demanded immediate conformity to the ways and values of their European slave owners (the colonists) (Southern and Wright 1990). Both men, women, and children were workers who worked side by side in fields, forests, workshops, and households. Black women were made to produce children between every two and half years from age 19 till the age of 40. All children born in slavery were auctioned out into perpetual slavery. About onethird of slaves' first marriages got broken by sale of their children or they themselves to different slave owners, families, and children getting away from the slave-homestead. These unfortunate sales, death, and other factors stimulated African Americans to form families from non-biological kin, and unrelated adult orphans. Working adults shared childbearing, and good friends and supporters (non-kin) became 'brothers' and 'sisters' (Painter 2006). Taking into consideration the prevailing circumstances and power relations, Black people cherished all black children, even those born of shame, abuse, or weakness. Family and Religion helped keep the slaves from the dehumanization of slavery. These everyday experiences including the spirits of struggle and resistance of slaves in the plantations featured as text in the evolution of the spirituals in the pre-gospel years (1900-1920).

The beginning of gospel music cannot adequately be discussed without first acknowledging the foundation of its construction - the conversion of African slaves to Christianity. Before the eighteenth century, very few slaves had gotten converted to Christianity. 
Among other reasons, there was minimal interest in 'saving' the souls slaves, because there was the fear that the principles that served as the foundation for Christianity would impede the success of slavery as an institution. After the Second Great Awakening, however, there was a mass conversion of slaves to Christianity. Although slaves got introduced to a new religion, slaves did not reject the cultural aesthetics of their African heritage. New musical forms such as spirituals, gospel, and blues, Jazz are the musical genres of Black Americans created within the Black community under "conditions of social, economic, and political oppression (Hare 1973; Asante 1988; Talmadge 1990). Evidently, the spirituals helped blacks to evoke their feelings and at the same time consoled their misery by reminding them of a better place after death as they believed in the second coming of Christ that will free them from the traumatic torture of slavery (Painter 2006). Within the culture of worship experience, slaves characterized expressions and reflections of their songs within the context of performance as well as their expectations within the African American Community.

The evolution of the new musical forms, however, was not documented until 1867 when William Francis Allen, Charles Pickard Ware and Lucy McKim Garrison collected, compiled and later published the book Slave Songs of the United States. These authors described the slave songs as having "creative power" and "spirited." The songs and their composers and performers were seen as "musical talents."The intonations and delicate variations of the songs portrayed the peculiarity of the performers' voices. Another musical genre of historical import is the Negro Ballads that consisted of "not too infrequently striking sounds, slides from notes to the another, turns and cadences not in articulated notes; features that made it difficult to express the character of the songs (Allen \& McKim, 1951). In their thematic analysis of the songs, scholars identified features that they classified as sad, triumphant, resigned, expectant, grave, and light moods of the spirituals. For their part, the educational mission to the Port Royal Islands, a habitat of slaves, described the performers of this unique musical genre as "half-barbarous people" noting that nothing better could come out from them than "shouts" and "sperichils." Black slaves' worship, music and musical characteristics, and dance were described pejoratively by White scholars. While considering Allen and McKay's argument, it is also important to note the contributions made by (Burnim 2006, Raboteau 1980, Stucking 2002, Maultsby 1975 and Southern 1974) in the synthesis, analysis and detailed exemplification of African American music and musical traditions. For example, Burnim (2006) used data from two church populations - Mercy Mission Apostolic Church in Bloomington Indiana, and Grace Apostolic Church in Indianapolis - interviews from community members and secondary sources to give a vivid description of the musical performances of African American gospel music. She indicates that the characteristics that inform the aesthetic of gospel music performance, fall within three categories: 1) sound quality, 2) delivery and 3) mechanics of delivery. Burnim subdivides the "techniques and mechanics of delivery" into the manipulation of time, text, and pitch. Each of these categories contains qualities that require the embodiment of a performance by a performer as it pertains to different aspects. The Sound quality demonstrates the "communication of intensity and observable release of energy, subtle shading and contrast, yells, screams, shouts, moans, grunts and tonal contrast;" (Burnim 158) whereas the delivery styles embody the "total immersion of mind and body whereby the clothing and facial expressions" serves as part of the presentation." Gospel music is a music complex, which embodies ideology, aesthetic, and behavior (Burnim: 147). She affirms further that the music of Black people in the United States (156) is a product of Black culture, made up of qualitative standards such as is the case with.

Available research indicates that, in the 1920s and 1930s, Thomas A. Dorsey, known as "Father of Gospel Music," was reportedly prohibited from playing the "new gospel music" in leading African American churches because it was too "bluesy" or "worldly" (Harris, 1992, p. 179). The National Convention of Gospel Choirs and Choruses, which was sometimes referred to as 'Dorsey Convention,' served as a springboard for most of the female musicians. Clara Ward and Rosetta Tharpe are, indeed, two icons and performers of Gospel Music also made it through this platform (Ward 1956, p. 16; Maultsby, 1992, p. 23). Born and raised in Philadelphia, and on a farm in Arkansas respectively, Ms. Ward and Thorpe were persons of significance during their respective lifetimes. They rose through the ranks in the field of gospel music to achieve the fame they enjoyed in the musical world. However, as women, this was not the time that they were free to assert themselves fully in all the ways that they preferred, mostly because men constituted the bulk of the musicians at the time.

\section{Rosetta Tharpe}

The birth of Rosa, Rosie Etta, or Rosabell (for she had many names before she became internationally known as Sister Rosetta Tharpe), was perilous from the start. Her biological parents were Katie Harper and Willis (Willie) Atkins. Her mother, Harper, was thirty-two whereas her father, Atkins, was fifty-seven. She was born on a farm just outside a cotton plantation on March $20^{\text {th }}, 1015$ in Arkansas. Mr. Atkins was a farm laborer and later worked for the Pacific Railroad, both as a tie cutter. He helped build highways doing construction from Arkansas to Missouri. 
Both of Tharpe's parents were ardent Christians and belonged to the church choir of the Church of God in Christ (known by the acronym of COGIC), where they believed that they could affirm their sense of black community and humanity. Indeed, Roy T. Scott, the grandson of Mr. Atkins, (Rosetta's father) explained in interviews how the grandfathers' clear, booming voice could be heard from across the fields. They were very particular about exhibiting holiness living, as well as the intensity with which they expressed themselves through music and its accompanying faith dance. These qualities gave young Rosetta her initial exposure to religious songs, which subsequently shaped her life.

It is also important to note that affirming the sense of community (black community) and humanity mentioned above was quite significant to black people at the time. It is notable that, one of the mechanics of slaveholders in the United States to discourage and suppress slave rebellion was to exploit the different ethnicities, belief systems, language, culture, and traditions. The tradition involved mixing of such different background to ensure miscommunication. Despite this tactic, slaves still forged a sense of identity through their verbal and artistic expression, folklore, dance, and music. This situation is what goes to confirm the humanistic bond that exists between black communities (Herskovits 1990; Wilson 1992; Maultsby 1990; Kubik 1999; Monson 2007).

Coming from such beginnings, Rosetta grew up to become gospel music's first national star as well as a thrilling celebrated guitarist and a pioneer of modern rock-and-roll guitar. With the spirit of boldness and enthusiasm, she ended up concentrating on the guitar although her fingers could hardly reach the strings. At age four, she began performing in churches and revivals and had compositions and arrangements to her credit.

In 1971, Rosetta Tharpe e got tagged as a "special child" because of the skillfulness, with which she played the guitar and 'accompanied' herself as she sang Gospel Music. Her mother (Katie), who eventually became a preacher, pursued her evangelism work within churches affiliated with the Church of God in Christ (COGIC) by traveling with her daughter to worship at church events in Chicago, Illinois, in 1921. One of Rosetta's fondest memories was how she would sit on her Mom at church while she played the piano and sang, "Nearer my God to thee," with one finger on the Harmonium, and her Mom accompanying her with her left hand. Rosetta eventually ended up concentrating on the guitar although her fingers could hardly reach the strings. She had several compositions to her credit.

\section{Rosetta's works: Affinity between Gospel and Jazz}

Among the realms of gospel and Jazz of all nations, Rosetta's name shines because of her exuberant self-expression and incorporating elements of gospel, blues, jazz, traditional ballads, country, rhythm and blues into her music. She did perform at church, storefront and tent meetings and venues such as cotton clubs and Harlem's legendary Apollo Theater, but most importantly her performances in the secular settings jumpstarted her recording debut with Decca Records. She produced songs backed by "Lucky Millinder's jazz orchestra encompassing titles such as "I Look Down the Road and I wonder." Others were "My Lord and I," "Savior, Don't Pass Me By," "That's All," and "The Train," titled "Eighteen Original Negro Spirituals."

In 1938, still something of an oddity, she joined the Cab Calloway band at the Cotton Club, where she sang decidedly secular tunes such as "Rock me" and "Pickin' the Cabbage." Sister Rosetta (popularly called) played the Apollo several times with Calloway, and then with Lucky Millinder, with whom she recorded "Trouble in Mind."

By the early forties she was a famous soloist, usually performing swinging jazz numbers, but by the mid-forties, she returned to a religious repertoire. Sister Rosetta remained true to her love of jazz, too. When she thrilled the Apollo audience with inspirational songs like "Jesus is Here Today" or "How Far from God" she has often been accompanied by jazz great's life George "Pops" Foster, the bassist, or Kenny Clarke, the pioneering bebop drummer. Sister Rosetta Tharpe, the Pilgrim Travelers, the Five Blind Boys, and other gospel performers, in the late forties, turned their gospel sounds into hit records making the Rhythm and Blues $(R \& B)$ charts. By the 1950s gospel had become the hottest black musical form; meanwhile, the moral conventions of the gospel lifestyle prevented the sound from being in the theaters like the Apollo.

Sister Rosetta's recognition was and has been phenomenal given the uniqueness of her music repertoire and style which showed an affinity between gospel and jazz that all fans could recognize and appreciate. These qualities made her an instant success. Many worshippers were impressed and even 'stunned') at her ability to mix sacred and secular music performances to create a new musical genre that was unique in text, context, style and vocal rendition.

From the late thirties until the instruction of the gospel shows in mid-fifties, virtually the only gospel singer to play the Apollo was Sister Rosetta Tharpe. The mid-1950s and early 1960s marked difficult times for gospel artists as it was blasphemous to perform in nightclubs. 
Performers such as Rosetta Tharpe and Clara Ward had to defend their decisions for taking this grim route to reach out to the crowd outside the four walls of the church. At a Paris post-performance, the press asked Clara about the objection to singing in nightclubs and Disneyland? She said in response:

"When we sing you can call it a religious service or a concert- it can be both. An audience is sometimes a religious group, and if they are not, they get a good feeling anyway- and that may be the start of a productive relationship with the Holy Spirit. Our mission, our purpose is to help mesh the mind, spirit, and soul into a sweeter, more loving partnership, to introduce the beauty of our Lord." Willa-Royster p. 163

Gospel singing derived from the freestyle collective improvisations of the black church congregation and the rhetorical solo style of the black gospel preacher makes it solely a church affair (Williams-Jones 1975:381). Church folks also believed that salvation from God is drawn from the good works of the gospel singer and preacher at the church. Therefore, Sister Rosetta and Clara Wards claim of evangelism in the nightclub ignore the interplay of these two ideologies. Mahalia Jackson, a consummate vocal artist in the gospel tradition, preferred to side with the church folks' thinking. The popularity of gospel music was to "raise the spirit" and ultimately create a "sense of euphoria and release" for black Christians. This popularity was not an opportunity for its performers to present at in places like the Apollo.

Most religious blacks considered the Apollo Theater to be a place of sin. Ted Fox (1983:225) in his book "Showtime at the Apollo" writes

Clayton Riley, the writer, remembered an elderly neighbor woman preaching to him that "the Apollo Theater is the devil's house, young man; righteous folks don't go in there and sinners can't rightly find their way out." The greatest gospel soloist of all time, Mahalia Jackson, never appeared at the theater even though her friend, Thurman Ruth, another prolific gospel artist, repeatedly tried to convince her that an Apollo appearance would benefit her and her followers. Thurman Ruth mentioned how difficult it was to convince gospel singers to perform at the Apollo as gospel music was considered to be sacred and making its performance at the theater a sinful act!

Many Black-Oriented Radio stations will broadcast Black music (especially gospel) at non-peak hours. One such Black-Oriented Radio station, WLAC, was in Nashville. Its programming did not separate gospel clearly from Rhythm and Blues, so it blurred the sacred-secular line. The music industry exploited singers, making a lot of money without letting the music reach the performers themselves. Record labels paid gospel singers to sing other forms of musical genres. Some felt that the line between gospel and R\&B was just a matter of the song texts rather than its original musical content. For example, in Ethnomusicologist Portia Maultsby's, "The Impact of Gospel Music on the Secular Music Industry," highlights the misinterpretation of a 1987 Billboard article about commercial gospel's religious and cultural significance. In her discussion of the importance of this mistake, Maultsby contends that many popular misconceptions about the genre are a result of its exploitation and commodification. Gospel music exploded in popularity in 1970s-1990s. It now exists in a wide range of settings, and in many forms, and is much more widely available in commercial recordings. The genre's crossing over potential was significantly affected by Edward Hawkins singers "Oh Happy Day" in 1969. Hawkins's combination of gospel and soul elements, makes her music danceable and help amplify its popularity, authenticity and communal and public appropriation. His primary interest, however, is to declare that "Gospel elements have been appropriated, then re-injected, generating new styles everywhere ( Maultsby 19870 " This process has resulted in continual blurring generic lines just as much as sacred/secular music in reference to Ms. Rosetta Tharpe and Clara Ward's initial assertion mentioned above.

As Gospel Music traditionally found its way into the public venues, Tharpe appeared in John Hammonds 1938 Historical Musical Event dubbed "From Spirituals to Swing" at CafZ Society with Cab Calloway and Benny Goodman in Carnegie Hall. At the time, except for one brief experience at the Cotton Club, Rosetta had never sung anywhere except in Negro Churches. This eventually led to a second "Spirituals to Swing" concert in 1939 (Hammond and Townsend 1981, 231). Songs like "This Train" and "Rock Me" featured prominently. Tharpe became known as "gospel's original crossover artist" and the genre's "first nationally known star (Wald 2007, p viii) when her recordings achieved mainstream commercial success.

Moving on, Rosetta's song, "Strange Things Happening Every Day," recorded in 1944 with Sammy Price, Decca's boogie-woogie pianist, showcased her virtuosity as a guitarist and her witty lyrics and delivery. This recording received sharp criticism from the religious community as 'devils' music.' At the time, it made Billboard's "race records" Top Ten, which she proficiently won many more times in her career. Recordings such as; "Shout Sister Shout," "That's all," and "I want a Tall Skinny Papa" which was accompanied by Lucky Millinder's orchestra was the first secular hit records during time which Tharpe played the electric guitar. 
Tharpe became a national celebrity, receiving lots of publicity, recording dozens of songs, several which became hits on the race record charts (Reitz 1988). Among the swing bands and musicians that Tharpe recorded and toured with include; The Dixie Hummingbirds and The Golden Gate Quartet, Sam Price Duo, Marie Knight, Noble Sissle, Lucky Millender Orchestra, and the Rossette Gospel Singers. Eventually, for her Precious Memories album, recorded for Savoy in 1968 (Wald, p.196) Tharpe earned a Grammy nomination, continued to make television appearances and continued to tour the United States and Europe.

Tharpe's capitative performances, unique fingerpicking style on the guitar, upbeat songwriting and arranging perspective are widely recognized as characteristics of rock n' roll. A documentary of Tharpe's career accurately describes her as the "Godmother of Rock n' Roll (Csaky 2011) and fittingly accorded a "rock n' roll trailblazer" by Gayle Wald (Wald 2007). Likewise, the United States Library of Congress' inducted Tharpe's 'Down by the Riverside' (1944) into the National Recording Registry in 2004, as postulated by (Cannady 2005) as result of her "spirited guitar playing" and "influence on early rhythm -and-blue performers."

The influence of Tharpe's play and performance style on Chuck Berry; a player often considered the progenitor of rock n' roll guitar and showmanship are phenomenal. Chuck Berry was a one-star rock n' roller of the later 1950s whose success, both musically and lyrically was rooted in the black musical tradition (Fryer 1981). And it is the case that, Berry not only used the black culture to formulate and structure his songs, but he also used the perspective handed down through that tradition. Berry, the singer for the Dixie Hummingbirds gospel group, stated "Yeah, Check Berry got a lot of that stuff from her Gayle Wald (2007 p191). Not only Berry but Geraldine Hambric, a Chicago gospel singer and a contemporary of Tharpe also commented that "when Chuck Berry came out, I had seen all that (ibid 71)" signifying a connection between his and her style. It is clear that Sister Rosetta Tharpe's musical career, explicitly and implicitly influenced subsequent generations of guitar players and performers.

It is also worth mentioning that 'Sister' Rosetta a name she will acquire later in her career was one of the only two gospel groups at the time to record V-discs (V stood for "Victory") for troops overseas. Putting together a captivating voice duo comprising of Sister Rosetta Tharpe and Marie Knight (by Decca records), they toured the gospel circuit for many of years. For her popularity, Tharpe attracted 25,000 paying customers to her wedding to her manager Russell Morrison (her third marriage), followed by a vocal performance at Griffith Stadium I Washington, DC in 1951.

As it turned out, Ms. Tharpe's popularity waned in the 1950's when African American picture magazine 'Our World' published a lengthy piece about the "new rage" in spiritual singing. A twenty-eight-year-old Philadelphian who became a prosperous star while turning down offers of "as much as $\$ 10,000$ to switch from gospel songs to the blues" made the headlines. This new gospel star was Clara Ward of the Ward Singers who had come into fame with their debut "Surely God Is Able." Clara was Slim and light skinned, considered prettier and daintier a gospel princess well matched to an era and a culture that valued "petiteness" and refinement as feminine ideals." Very much unperturbed, Rosetta resurged in popularity in youth culture, secular outlets and a three-week tour to Europe that earned her \$28,500 equivalent of $£ 10.000$ which caused her rebirth as a star in Europe. Returning home to the United States, Sister Rosetta will fall back on the church, the womb from which her career evolved which was nowhere near her former celebrity status, and her inborn Christian beliefs. No matter the discouragements and setbacks the world threw back at her, Sister Rosetta finally settled at the Pentecostal church where she cut her teeth in the music world. It is worth noting that, Rosetta, did have her time with people like; Mahalia Jackson, The Hummingbirds, Sarah Lottie, Maries Knight on stage including shows such us Perry Como Supper Club show, the Newport Folk Festival, among others. Her dazzling guitar play influenced and popularized gospel music as she forged her career in the world of commerce. Her audience included a broad social spectrum that transcended racial, regional, and class division. Tharpe took her songs to the urban white, middle-class audiences when she set out to the cotton club in 1938. Her popularity and enthusiasm got also triggered by black audiences irrespective of social class.

Most of the songs written were in response to the frustrations and race discriminations of black people. They were both secular and sacred and also met the spiritual needs of the community. Also, the songs suggested solutions for personal problems on the black population living in newfound freedom. Hence the emergence of black gospel performers to engage people outside the church was welcoming to the community. Artists include C. A. Tindley composed in the 1890s and early 1900s, Lucie E Campbell 1927, Thomas Dorsey 1930s, Famous Blue Ray Singers of Birmingham, Alabama 1931, Sister Rosetta Tharpe 1938, Reverend W. Herbert Brewster 1940, Clara Ward, Marion Williams, and Mahalia Jackson 1950 and many more, made gospel much sophisticated and adventurous (Heilbut 1982:106). Notable among them is the pioneering trailblazer of a kind, Sister Rosetta, as the first to break barriers between sacred and secular music in 1938. For the record, she also sang gospel at the cotton club show in Harlem, and further sang gospel on a concert at Carnegie Hall, dubbed from "Spirituals to Swing." 


\section{Clara Ward}

Unlike the guitarist and vocalist that Sister Rosetta was, Ms. Clara Ward, had the qualities of a composer, recording artist and a prolific singer of a kind. Ms. Ward was born on the 21st of August 1924, to her Philadelphia-based parents, Gertrude Mae Murphy (affectionately referred to as Mom Gertrude) and George Ward. Mr. Ward was a foreman at an aluminum company, and Mom Gertrude was a house worker. Mom Gertrude was the eleventh daughter of the Murphy's sharecroppers in Anderson, South Carolina. The Murphy family was also very particular with church attendance and worship. Gertrude and other kids will trudge almost ten miles to attend Ebenezer Baptist Church, a oneroom structure that was also the schoolhouse; a place where Gertrude met George Ward and moved from Anderson, South Carolina to Philadelphia to live with her sister Clara and husband Hamlin. Soon after they settled in Philadelphia, they had their daughter, Willarene (Willa) and Clara Mac Ward.

Unlike Rosetta's Mom, Clara's mother was a gifted gospel vocalist on her own right and emerged among the most influential promoters in all gospel and entrepreneurship when, according to her, a vision commanded her to begin a singing career. This experience never lost its spell and can be traced in Clara Ward's works up to the last moment of her career and life. As it turned out, Clara did not have easy or smooth education, as she attended ten different schools, during which songs taught in an assembly room influenced her musical career as well. However, she finally dropped out of school because she could not keep up with schoolwork.

Clara's first public launching of her musical talents was on her baptismal day at five years old. At the time, she and her sister (Willa, aged eight), acted in a play called Heaven Bound, in which "the Devil" would try to entice the singers as they walked to the aisle. Clara strutted down, just singing her little heart out the song, "Oh when the Saints- go marching in- oh when the Saints go marching in- Lord, I want to be in the number, when the Saints go marching in." That was her first solo. Afterward, taking part in an audition and winning, her Mom would then refuse them (Willa and Clara) from continuing to sing at the talent show, "Kiddie Hour," which was aired every Sunday by Lincoln Theatre at Broad and Lombard Streets. It was because they were not allowed to sing church songs. Clara learned to play the piano and, at age twelve, had started touring with some well-established gospel musicians in the industry.

\section{Clara's works}

By the 1950's Clara had recorded some fifty singles and albums, which placed the Ward Singers at/in the forefront of Gospel Music. The mastery of design and fluency which distinguished Ms. Wards works featured in her compositions. Interestingly, their performances did not only revolve around the African American Church community but into the nightclubs. "How I got over" an old spiritual and "Surely" reworked became big hits in 1951 distinguishing Ms. Ward's mastery in composition design.

As a performer, Ward was influenced by blind Arizona Francis due to the pulsating tempo and vitality in playing the piano, and the captivating voices of Queen C. Anderson and Clara Hudson; this spur/ motivation liberated her and made her touch the lives of millions. This inspiration made 'Surely,' the group's greatest hit-song as it introduced a new Waltz rhythm that the Wards introduced into the gospel lexical repertoire. Preceding this success was Ms. Ward's playing and accompanying people like Mary Johnson Dans who traveled through the Eastern shore, and on into the South along with Bertha Wise and her chorus. Other prominent artists Ms. Ward played with were Mr. McCrae, manager of North Carolina Junior Quartet, Rev James C. Edwards, who sung at several churches and broadcast radio concerts on Sunday nights from the New Central Baptist Church, and who also performed at the Tuskegee Institute in Alabama. These functions got intertwined with the joyous tradition of celebrating the Ward Singers annually. Wellcelebrated gospel artists were invited to play so much so that it became a status symbol. Furthermore, besides Professor Dorsey and Sallie Martin, Ward performed with C. L Franklin, Mahalia Jackson, Rosetta Tharpe, Clara Hudson, James Cleveland, among others. It was at one of these anniversary functions that the Wards changed their name from "Consecrated Gospel Singers" to the "Ward Singers."

It is important to note that the Famous Ward Singers not only established a demeanor of female group in appearance but also defined female gospel 'sound' (tone tenor and rhyme). They knew their material so well, walked into auditoriums straight and proud, and burst into song on the same beat, same enunciation, same volume, same nuance, and same beauty (Ward-Royster \& Rose 1997: ix). It is therefore not surprising they won the gospel music category in 1952, 1953 and 1954 consecutively.

For seven years, the Ward Singers spent their summer working the Golden Horseshoe at Disneyland in California. "Walt Disney himself told us he loved our work so much that we had a home at Disneyland;" Ward said (Ward-Royster \& Rose 1997. 135). The Ward sisters pushed gospel music out of the church to the nightclubs, infusing their powerhouse voices and soul rhythms, and consequently becoming top attractions in the musical spheres. They also not only established 'demeanor' of the female group in appearance but also defined female gospel sound. 
What is surprising, however, was that the Christian community pressurized the Ward Singers about singing gospel at the nightclubs, Disney, and other secular ecologies. Furthermore, the Ward group received a lot of critique about their costume and hairstyle, but this is how Mom Gertrude addressed their critiques when she got confronted:

"I don't know if they've accepted it by now or not. They thought that when we went to the clubs, we we'd be singing blues and jazz or even rock- and -roll, but we sing the same songs in the clubs that we sing in church. It is beautiful how they accept Gospel singing, sometimes even more than people in the church. ...The Bible says, and Christ said to all his disciples, "Go ye into the world and preach the Gospel to every creature. He that believeth shall be saved, but he that believeth not shall be damned" Mark 16: 15-16.... People say we look like clowns in our gowns and wild hairdos. Can you imagine someone who is supposed to be a Christian concentrating on how we look rather than how many people we make conscious of the Lord's presence? We are not bishops or tribal leaders, but we are messengers, and our "special looks" rings the bell so that we can get into your souls. Amen" Clara Ward added, "When we sing you can call it religious service or a concert----it can be both."

When reviewers asked about the crossover and how it came about, Ms. Ward countered her representation of the crossover with the arguments that the secular sector needed and deserved the music ministry. Ms. Ward noted that it was important to offer as much of her music to the secular world as she did (offered) to the churchgoing folks. She drew an analogy of her position with that of Sister Rosetta who also shared her views on this same subject. She posited that as a traditional musician, she saw herself as doing God's work even if the 'mixture' of sacred and secular performances stunned or made worshippers uncomfortable.

Miss Ward underscored:

"A gospel singer cannot be satisfied without living and breathing every word he or she sings. Just like friends, Gospel songs cheer folks when they're downhearted, and they give people hope to continue their daily lives even when times look bleak. They can bring sweet and beautiful messages to the lonely and the sick. Perhaps this explains how we cannot turn our backs on requests from the audience. You never know just how much it might mean to the requester. It is by no means an easy life, but it is impossible to resist the joy of bringing happiness to people- people everywhere. The body gets tired, but to me, it's the most satisfying of all possible exigencies. ...".

This bold step taken by the Ward Sisters augmented their invitation list countlessly. For example, they performed at Knoxville Tennessee, Carnegie Hall in New York, Jazz Festival, and in New Port (Rhode Island) in 1975 marking the first time a gospel group ever performed there. They also carried out on stage with famous greats such as Gospel Harmonettes, Elvis Presley, and Mahalia Jackson. Clara was acclaimed as among "the people who saw the great need," when she immediately canceled five weeks of engagements to accept invitations of Department of State, and the USO (United Service Organization) to visit Vietnam for three weeks. Listening to the praise showered on her and the group, this what she told the press:

"The morale among the men was so very high. It made me happy to be able to live their spirits. The ratio of Negro to white was about 1 to 4, 25 percent. What I saw 100 percent appreciation from a group of American guys united in a common cause (Ward-Royster \& Rose 1997. 165-166)."

It is not surprising that with these manifold and varied activities, which increased when she settled in California in the mid 50's, Ward's output as a composer, arranger, and soloist became incessant. Whatever else claimed her attention, and she touched nothing timidly or half-heartedly, the time she reserved for creative work was seldom allowed to be disturbed. There was no performance that she would slacken in the mercy of disgrace and disappointment. She sung beautifully, and not only were her performances exquisite and profound, but they were there talked about (Ibid).

Clara Ward and the Ward sisters took the continent by storm, which had much to do with consolidating their positions as musicians with awards. These two prolific gospel artists' musicals careers underwent certain challenges, which were quite similar to that of Rosetta with a little variance. Sister Rosetta being the first female gospel musician intersecting and overlapping religious music at secular stages bridged the standard of holiness and respectability for the church. This development brought a lot of controversy and backstabbing. But for her, it never mattered whether her listeners were "saved" only that they got something from her music, but the crossover caused a significant controversy among the fans of both Clara Ward and Sister Rosetta. 


\section{Biggest Challenges \\ Gender}

Rosetta Tharpe's greatest challenge was gender related; in particular, the fact that she played the guitar, a male dominated musical instrument, made her quite odd. She was seen as intruding and appropriating a male-dominated musical sphere and space. This predicament made it difficult for her to play with other bands as men already dominated guitar-playing leaving her with no role in that 'department' To secure her identity in the context of volatile economic circumstance and the promotion of her career in the industry, Ms. Tharpe was left with little or no choice than to perform in church. It came as no surprise when she eventually joined the fleet of gospel artists who performed in traditional venues such as concert halls and recording studios. The Black church ignored the gospel artists because they played secular musical styles and associated them and their work with secular records (Weekes 2005). Despite switching to secular music, Ms. Tharpe saw the opportunity of reaching out to people outside the church; it was a chance to reach out to individuals who needed to be reached out to with the same music sung in the churches. With respect to costumes and props, Rosetta did not dress like those other women in the secular music industry. She wore clothes that covered up her body without showing/revealing 'questionable' parts of her body. She did not wear jewelry, and the songs' lyrics were inspirational and didactic. According to Ms. Tharpe, the songs were still the same, but the audience changed.

\section{Racial Segregation}

Racial segregation was a big challenge, as Rosette Tharpe and her special assistant, Marie Knight were not allowed to use public facilities in the towns where they performed. They either stayed in someone's home (preferably black person's home); lived in tour buses or the black funeral homes. The 1940s through to the 1950s saw the Jim Crow Laws, the Supreme Courts' "separate but equal" legal doctrine for facilities for African Americans. It is safe to say that gospel performers before Sister Rosetta's tenure such as; Ward Singers, Dinah Washington, Davis Sisters, Roberta Martin Singers, and original Gospel Harmonettes, and quartets like, the Soul Stirrers, Pilgrim Travelers, Dixie Hummingbirds, and Five Blind Boys, -to mention but a few-were not perturbed with the gruesomeness of the Jim Crow Laws. Instead, Black gospel artist received a tremendous increase in exposure and distribution of gospel's new leap of prominence (Heilbut.1982; 110).

Another challenge was 'hustling and competition' Like any other music career, the struggle to maintain the popularity when new artists emerge was something Rosetta and Ward had to contend with. Sister Rosetta experienced this ordeal with the emergence of artists such as Mahalia Jackson, Clara Ward and the Ward Singers as they 'lowered' her stardom. Men also did not give her credit because she was in competition with them. As much as she managed to survive her volatile economic circumstances, she stayed away from divorce and finally settled with her third husband until her demise. At a point in her life, although she sang about the wages of sinful living, she pursued romantic relationships, primarily with men but occasionally with women. Eventually, she got accused of a relationship with Marie Knight as a deeper one than implied which was a hard nut to crack looking at the caliber of her work.

Although Sister Rosetta did not come out clearly on this accusation, Clara Ward in a conversation with her sister, Willa, revealed her 'dabbling' to the strictures of dating men imposed by their mother, the 'daunting' Gertrude Ward (Mom). Also, loneliness and vulnerability rendered her prone to anything that filled the void in her life. Rosetta's Mom, Ma Bell, however, was decidedly less enthusiastic about her daughter's activities, but she never stood in her way.

Despite being an acclaimed soloist in Gospel Music genre, Ms. Ward faced challenges that resulted in various personal inner suffering. Thus, even though people associated Gospel Music with inner peace and comfort, Ward faced challenges any average person faced. This issue eventually caused her health to decline and, subsequently, forced her into retirement as well. One major problem that Ms. Ward had with her career was her mother, Mom Gertrude. She was overly controlling and evil. She made Clara play the piano two or three times a day to see if affected her ability and skill although she had a stroke (Ward-Royster \& Rose 2007:182).

Even though Gertrude was viewed as controlling and evil, it is worth placing her behavior in a socio-historical context. Thus, it is important to reminisce on her sordid past. Specifically, the remnants of slavery caused its descendants to be over-protective of their family and children in general. For this reason, Gertrude was 'controlling,' because first, she needed to protect her own, without Clara she had no money, she had her meal ticket and believed that marriage would take her away from her career.

Mom Gertrude make Ms. Ward sing at church every night until everyone had shouted; and when she refused to do sing, she would beat her up with a broom handle; something that will in modern times be viewed as abusive and could have resulted in her imprisonment. Also, whenever they performed at the Nightclub, Gertrude made sure Ward did not interact with the other artists because she claimed they were 'devils.'

Also, she would not allow her to rent a place of her own; she rejected the idea as 'foolish and wasteful." Gertrude made 
Ms. Ward play the piano two or three times a day insisting it will improve her dexterity test and make her sleep well. In fact, whether or not Ward complained of fatigue did not make Gertrude budge; she brushed the complaints aside saying the benefits of practicing far outweighed the fatigue. Being completely shorn of self-control, taking solace to singing the gospel and slurping the booze, was how Ms. Ward put it in a letter to her sister, Willa. She noted, "The only way I can survive is to drink, if I didn't, Mom would drive me crazy or give me a heart attack. God help me."

To overcome her challenges, she thought that marriage would insulate her from all harm and provide consent happiness. The main thing she was looking for was cutting off the chains that bound her to Mom Gertrude's domination. She tried several romantic relationships and marriages but none of them thrived, and with all the opposition and pressure from Mom Gertrude Ms. Ward ended up in lesbianism and excessive drinking.

Unfortunately, Ms. Ward collapsed and was diagnosed with a severe aneurysm and stroke. The prognosis was not good making her accuse Mom Gertrude of the cause of her situation. She fell into a coma for a week and did not survive it. After her death, Clara Ward was remembered for her talent, and her love of gospel music and God.

As per memorials, Savoy Records Catalog: 14300 has a "Clara Ward Memorial Album" to her credit. There is also a memorial album on vinyl records, CD'S and LP's and finally a grave memorial in her honor. Ward got commended with the issuance of the commemoration of a state stamp together with Rosetta Tharpe, Mahalia Jackson, and Roberta Martin. Sister Rosetta featured in performances "Up Above My Head" and won the award-winning French Film Amélie in 2001.

Rosetta Thorpe was a woman of many guises; crossed and re-crossed the line between secular and sacred sound. Ms. Tharpe suddenly fell ill, suffered a stroke due to complications from diabetes and had a leg amputated. She, however, continued to perform until she suffered a second stroke and passed away days later at the age of 58 in 1973.

\section{Conclusion}

In this study, I have compared the lives and professional record of two prolific female artists — Clara Ward, and Rosetta Tharpe-. I have relied on such primary-source and secondary-source materials as their biographical information, their musical contributions, distinguishing characters, their famous songs and, most importantly, the challenges that they faced as pioneer female gospel artists, who switched from the sacred to the secular music world.

In Outlaw Culture: Resisting Representations Bell Hooks (Date) explores the internal workings of cultural practices and cultural icons, which she defines as on edge, as pushing the limits, disturbing the normal, of acceptable politics of representation. Clearly, the women of gospel music I have discussed fit this description. They are ordinary women who led extraordinary lives just because they refused to be limited by tradition, by conventional wisdom, or by images that restricted the world they envisioned. Their ability to successfully negotiate the limiting power of these constructs depended primarily on the artistic ability to recognize their existence. Women in gospel music had to be alert, resourceful and resilient to achieve their musical and spiritual goals.

The decision of the two women (Ward and Tharpe) to perform gospel music in secular settings was groundbreaking. Furthermore, they managed to sustain their careers and successfully endured the encounters and controversial judgments of the Christian community. They both utilized the same tool, conscious act of resistance, which African Americans had used with such success during the period of slavery and the fight for civil rights. Both are credited with popularizing the Pentecostal performance styles that would go on to shape both the secular and the sacred worlds. Indeed, they did get along in their extraordinary ways. They sacrificed much and fought long and hard, and at times grew weary; but their sense of mission, their calling, never allowed them to give up. Horace Clarence Boyer, the Gospel scholar, among other details, said about Ms. Thorpe: "Sister Rosetta Tharpe did more than anyone else in introducing the music of the Negro Church to the World (1995: 210)"

\section{End Notes}

Wald F. Gayle 2007: Shout Sister Shout: The untold Story of Rock-and Roll Trailblazer Sister Rosetta Tharpe. Beacon Press, Boston. 1-2

Holiness living referred to the rigid standards of clean living- no alcohol, tobacco, gambling, social dancing, or other behaviors that might be construed as worldly. Pg. 8

Wald and Gayle 2007. Pg. 2

Ward-Royster, Willa, and Toni Rose. 1997. How I got over: Clara Ward and the world-famous Ward Singers. Philadelphia: Temple University Press. Pg. 22

Rosetta's 1958 stories 
Count Bassie is the leader of a star-studded swing band; they also performed on the same stage with Rosetta Tharpe at Carnegie Hall concert "From Spirituals to Swing."

JAZZ ROOTS RHYTMS: Celebrating Jazz \& Global Music; Sister Rosetta Tharpe Biography.

Wald F. Gayle 2007: Shout Sister Shout: The untold Story of Rock-and Roll Trailblazer Sister Rosetta Tharpe. Beacon Press, Boston. Pg. 141

I will use Clara and Ms. Ward interchangeably where appropriate

Clara's explanation to reporters about the crossover. Pg. 133

Ward-Royster, Willa, and Toni Rose. 1997. How I got over: Clara Ward and the world-famous Ward Singers. Philadelphia: Temple University Press. Pg. 162

Wald F. Gayle 2007: Shout Sister Shout

Interview with Tharpe biographer Gayle F. Wald, from WILL AM radio (an NPR and PBS affiliate), February 22, 2007- http://www.will.uiuc.edu/media/aftmag070222.mp3

\section{Bibliography:}

Allen, William Francis, Charles Pickard Ware, and Lucy McKim Garrison ([1867]1951. Slave songs of the United States. New York: Peter Smith.

Anderson, Talmadge. 1990. Black Studies: Theory, Method, and Cultural Perspectives. Pullman, Wash.; Washington State University Press.

Asante, Molefi K. 1988. Africentricity. New rev. ed. Trenton, N.J.: African World Press.

Allgood B. Dexter. 1990 "Black Gospel in New York City and Joe William Bostic, Sr. in The Black Perspective in Music, Vol. 18, No. 1/2. Pp. 101-115.

Burnim Mellonnee. 1985. "The Black Gospel Music Tradition: A Complex Ideology, Aesthetic and Behavior." In More than Dancing: Essays of Afro-American Music and Musicians, edited by Irene Jackson Brown, 147-167. Westport, CT: Greenwood.

Burnim, Mellonee V., and Portia K. Maultsby. 2006. African American music: an introduction: Women in African American Music. New York: Routledge.

Burnim, Mellonee. "Black Religious Music" in African American Music: An Introduction, ed. Mellonee Burnim and Portia Maultsby.New York: Routledge, 2006, pp. 51-78.

Hammond, John, and Irving Townsend. 1981. John Hammond on record: an autobiography. Harmondsworth: Pengu

Hare, Nathan. 1973. "The Challenge of a Scholar," in The Death of White Sociology. Edited by Joyce A. Ladner, p. 76. New York: Vintage Books.

Helibut Anthony. 1982 "The Secularization of Gospel Music" in Folk Music and Modern Sound. William Ferris and Mary L. Hart eds. Jackson: University Press of Mississippi, 1982), 101-115

Horace Clarence Boyer. 1995. How Sweet the Sound: The Golden Age of Gospel. WashingtonElliot \& Clark. 272 pp.

Hooks, bell. 2006. Outlaw Culture: Resisting Representations. Routledge Classics; 1 edition.May 14. 320 pages.

Nell Irvin Painter. 2006. Creating Black Americans: African American History and ItsMeanings, 1619 to the Present. Oxford University Press. Oxford.

Reagon, Bernice Johnson. 1992. We'll understand it better by and by: pioneering AfricanAmerican gospel composers. Washington: Smithsonian Institution Press.

Reagon Johnson and Maultsby Portia. 1992. We'll Understand It Better By and By: The Impactof Gospel Music on the Secular Music Industry. Smithsonian Institution Press, Washington, D. C.

Wald, Gayle. 2007. Shout, sister, shout! The untold story of rock-and-roll trailblazer SisterRosetta Tharpe. Beacon Press, Boston Massachusetts.

Ward-Royster, Willa, and Toni Rose. 1997. How I got over: Clara Ward and the world-famous Ward Singers. Philadelphia: Temple University Press.

Melinda E. Weekes, "This House, The Music: Exploring the Interdependent Interpretive Relationship Between the Contemporary Black Gospel Church and Contemporary Gospel Music," p. 43-72.

Maultsby, Portia K. "The Impact of Gospel Music on the Secular Music Industry." In We'll Understand it Better By and By, edited by Bernice Reagon, 19-33. Washington, D.C.: Smithsonian Institution Press. 